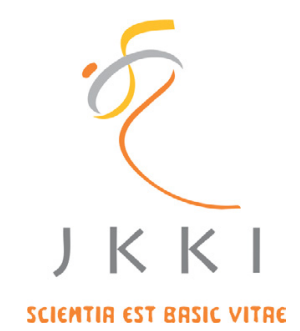

Jurnal Kedokteran dan Kesehatan Indonesia

Indonesian Journal of Medicine and Health

Journal homepage : https://journal.uii.ac.id/JKKI

\title{
Roles of doctors at health centres in applying principles of family medicine to prevent diptheria in Banda Aceh
}

\author{
Zahratul Aini*1,2, Eti Poncorini Pamungkasari², Ari Probandari² \\ ${ }^{1}$ Department of Family Medicine, Faculty of Medicine, Universitas Syiah Kuala, Banda Aceh, Indonesia \\ ${ }^{2}$ Magister of Family Medicine, Universitas Sebelas Maret, Surakarta, Indonesia.
}

Original Article

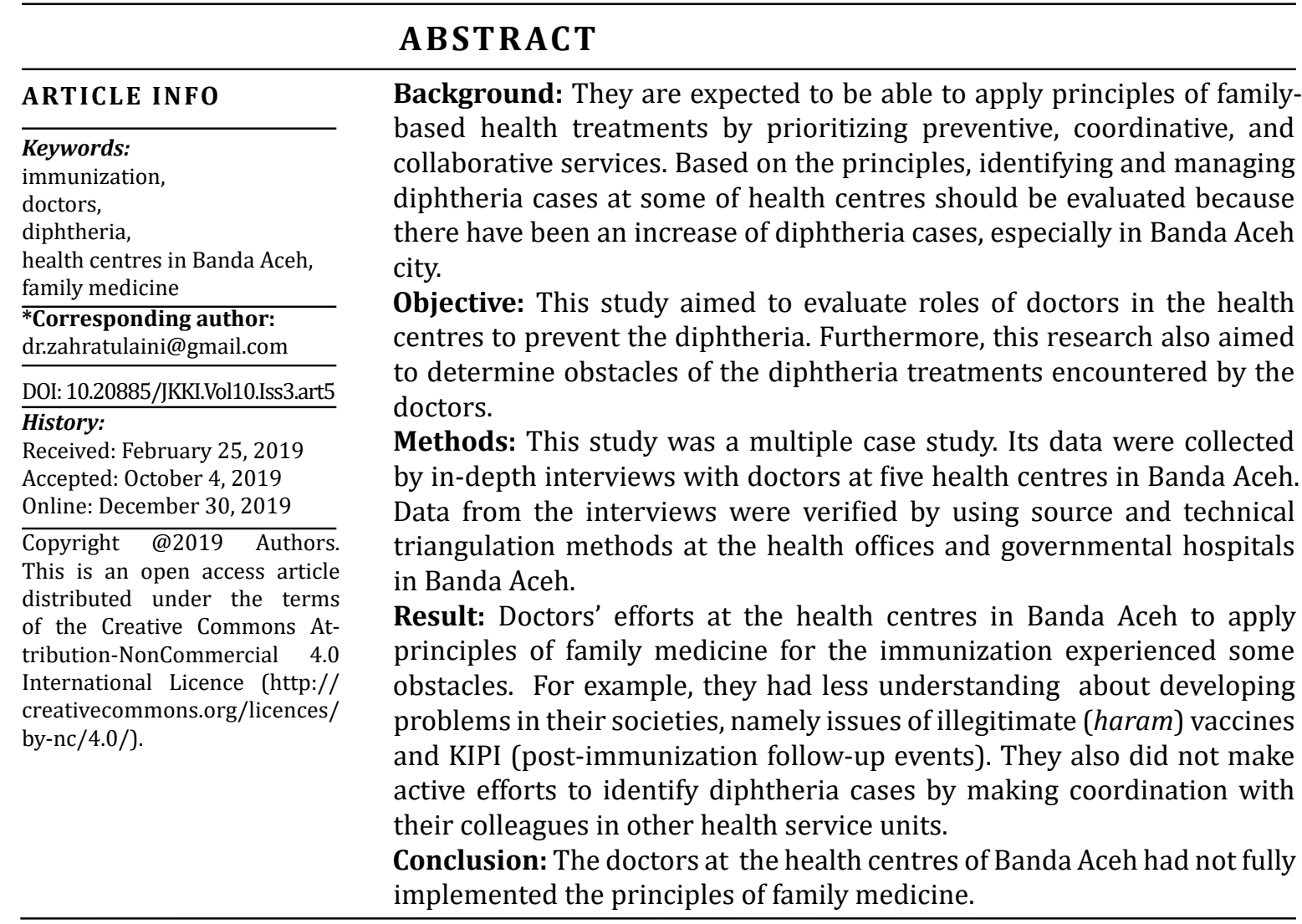

Latar Belakang: Dokter puskesmas diharapkan dapat menerapkan prinsip kedokteran keluarga dengan mengutamakan pelayanan yang bersifat pencegahan serta koordinatif dan kolaboratif. Berdasarkan prinsip inilah tindakan penemuan dan penatalaksaan kasus difteri di tingkat puskesmas harus di evaluasi lagi mengingat masih banyaknya penemuan kasus difteri di kota Banda Aceh.

Tujuan Penelitian: Penelitian ini bertujuan mengevaluasi peran dokter puskesmas dalam menerapkan prinsip kedokteran keluarga dalam mencegah difteri. Selain itu juga untuk mengetahui hambatan apa saja yang ditemui dokter puskesmas dalam melaksanakan kedua program pencegahan difteri tersebut.

Metode: Penelitian ini bertujuan mengevaluasi peran dokter puskesmas dalam menerapkan prinsip kedokteran keluarga dalam mencegah difteri. Selain itu juga untuk mengetahui hambatan apa saja yang ditemui dokter puskesmas dalam melaksanakan kedua program pencegahan difteri tersebut.

Hasil: Upaya dokter puskesmas untuk penerapan prinsip kedokteran kelurga dalam hal peningkatan cakupan imunisasi menemui kendala dengan kurangnya pemahaman dokter akan permasalahan yang 
berkembang dimasyarakat yaitu isu vaksin haram dan KIPI (kejadian Ikutan Pasca Imunisasi). Dokter juga tidak melakukan upaya aktif penemuan kasus difteri melalui koordinasi dengan teman sejawat di unit layanan kesehatan lain.

Kesimpulan: Dokter puskesmas di Kota Banda Aceh belum sepenuhnya melaksanakan prinsip kedokteran keluarga yaitu komprehensif, kontinyu dan koordinasi.

\section{INTRODUCTION}

Diphtheria is a contagious and infectious disease caused by Corynebacterium Diphtheriae. The disease is worrying because it can lead to complications or mortality. ${ }^{1}$ Moreover, when there is only one occurrence of diphtheria in an area, the area can be identified as an outbreak area (KLB) and should receive a serious attention from a government. ${ }^{2}$

According to the head of the infectious diseases section in Dinas Kesehatan Aceh, as reported by Merdeka.com on thursday, July 26, 2018 entitled "Aceh becomes the third province in indonesia with the most diphtheria", it was revealed that in 2017, Aceh was the third largest province with diphtheria sufferers after East Java and West Java. The numbers of diphtheria patients increased immensely in 2017. There were 113 cases occurred in Aceh after only eleven cases were found in 2016. Until June 2018, there were 143 reported diphtheria cases in Aceh. Banda Aceh as a capital of province of Aceh had become the highest numbers of diphtheria patients among 13 other districts. From 143 cases in 2018, 24 cases occurred in Banda Aceh. $^{3}$

The occurrence of diphtheria outbreaks in Banda Aceh indicates that there is a need to evaluate implementation of the disease prevention so that the outbreaks will not recur. Doctors at health centres (called puskesmas in Indonesia) as a gatekeeper are considered necessary to improve their abilities to prevent and deal with the diphtheria cases in Banda Aceh.

Ministry of Health of Republic of Indonesia has established seven guidelines for prevention and control of diphtheria. Two of them, the most important ones, are to increase immunization of diphtheria and to identify diphtheria cases earlier in order they can be solved soon. ${ }^{4}$

Previous studies have shown that completely basic immunization is a component that greatly influences risks of diphtheria in East Java in 2016 compared to its population density, which is 0.33 times. ${ }^{5}$ According to data from the Ministry of Health, Aceh is one of the provinces with the fourth-lowest complete immunization coverage for infants after North Kalimantan, Papua and Maluku. An indicator of successfully completely basic immunization for infants in Indonesia in 2016 was $91.58 \%$, while a report of complete immunization coverage for infants in Aceh was only $69.11 \%{ }^{6}$

Coping with the diphtheria outbreak, doctors at health centres is necessary because they are a gatekeeper of public health service in their working areas. They are expected to be able to apply principles of family medicine by prioritizing preventive, coordinative, and collaborative services. In terms of primary health care, they are required to be able to manage health problems in individuals, families, and societies in a comprehensive, holistic, sustainable, coordinated, and collaborative way. ${ }^{7}$ Based on these principles, their actions in identifying and managing diphtheria cases at health centres should be revaluated.

Previous researches on diphtheria in Indonesia found that factors influencing high incidences of diphtheria are immunization. However, they do not focus on which efforts that can be decided by the doctors at health centres to increase immunization coverage as a primary prevention effort. Never before had some researches discussed identification and management of diphtheria cases based on principles of family medicine.

Therefore, this study aims to evaluate roles of doctors at health centres to in implementing the principles of family medicine to prevent the diphtheria, including increasing immunization coverage, identifying and managing diphtheria cases in their working areas. In addition, this study is also to determine obstacles encountered by the doctors in implementing diphtheria 
prevention programs.

\section{METHODS}

This study was a multiple case study. It was conducted in Banda Aceh between June and October 2018. Its data were collected by in-depth interviews based on interview guidelines that had been prepared. Through in-depth interviews, the researchers more deeply explored problems that occurred, and interviewee could be more open about their opinions or ideas.

The main interviewees were the head of doctors in the health centres, or the doctors who have worked at the health centres at least one year. Each doctor was asked same questions about diphtheria prevention at the health centres. The questions were semi-structured, which interview guidelines and topics of the questions had been prepared before by the researchers, but the questions could be developed more deeply depending on the interviewees' answers.

Questions asked to the interviewees were about physicians knowledge regarding prevention and management of diphtheria by the Ministry of Health, diphtheria immunization at the health centres, numbers of immunization coverage, diphtheria education, and obstacles to increase immunization coverage. The researchers also asked questions about early identification and management of diphtheria cases that have been dealt by the doctors at health centres whether their approaches were active or passive.

The data of this study were selected by purposive sampling and criterion sampling. health centres, selected as samples, were those that were included in predetermined criteria. For examples, they were health centres that had positive diphtheria cases in 2018, became suspected diphtheria cases, and did not have diphtheria cases in 2018.

The selected samples were samples that were considered important and relevant to answer research problems of this study; therefore, the samples represented information instead of populations. In a qualitative research, the samples might not reach half of the populations because the qualitative research will be considered complete if there are no more data that are considered new or already saturated., 8

To some extents, selected samples of this study were based on endemic data of diphtheria obtained from the Banda Aceh health office. Five samples of health centres were selected because they could represent situations in Banda Aceh. The selected samples were coded by A, B, C, D, and $\mathrm{E}$.

The researchers used triangulation of data sources to improve validity of research results. Data sources in this study were health workers who handled diphtheria outbreaks in the Banda Aceh Health Service (T1) and expert doctors who handled diphtheria referral patients at the Public Hospital dr. Zainoel Abidin, Banda Aceh (T2). In addition, researchers also used the triangulation technique by combining interview techniques and collected archives or documents from key informants at the health centres.

Research ethic of this study was obtained from public hospital dr. Moewardi Surakarta (Number: 25/I/HEIC/2019). Before the interviews were conducted, each interviewee first signed an informed consent sheet as a proof of his/her willingness to provide information.

\section{RESULTS \\ Increased coverage of diphtheria immunization}

Educational efforts to increase immunization coverage were routinely conducted at each health centre. The efforts could be in forms of activities like counselling at the health centres or outside the health centres, distributing brochures, and installing banners in public places such as mosques, several buildings in the village and sub-district offices. The educational activities had become programs of the health centres funded by health operational assistance(BOK). Counselling also involved roles across sectors. The following is an excerpt from an interview of a doctor at health centre A:

"In addition to the counselling that we went to schools or across sectors, we conducted educational services outside the health centres 
such as posyandu (integrated service post for health). The posyandu was usually attended by health workers either doctors or paramedics who will conduct a counselling at the posyandu. Then through distributions of brochures, we also set up banners and standing banners in public places".

A triangulation informants at the Banda Aceh health office (T1) greatly appreciated efforts of doctors at health centres in Banda Aceh. He said: "In my opinion, I could say this because it is under my responsibility. The doctors at the health centres are very supportive and very cooperative in the immunization program. I think it also depends on how the community itself see or understand the benefits of immunization, but overall the doctors are very cooperative".

However, various efforts to increase immunization coverage conducted by the health centres had not been able to make immunization coverage reach national targets. The immunization coverage of the five samples of health centres was still below indicators of national immunization coverage, below $90 \%$ (Table 1).

Table 1. DPT immunization coverage of each sample of health centres

\begin{tabular}{ccc}
\hline $\begin{array}{c}\text { Name of Health } \\
\text { Centre }\end{array}$ & $\begin{array}{c}\mathbf{2 0 1 7} \\
\text { (January-December) }\end{array}$ & $\begin{array}{c}\mathbf{2 0 1 8} \\
\text { (January- June) }\end{array}$ \\
\hline Health centre A & $88.3 \%$ & $55.1 \%$ \\
Health centre B & $81.8 \%$ & $49.6 \%$ \\
Health centre C & $85.2 \%$ & $33.3 \%$ \\
Health centre D & $67.2 \%$ & $49.2 \%$ \\
Health centre E & $89.6 \%$ & $50.2 \%$ \\
\hline Source : Data archive of immunization coverage from each health centre
\end{tabular}

Immunization coverage below the national target is a big challenge for the doctors, especially to build public awareness of the importance of immunization. Main interviewees in all health centres acknowledged that the most important obstacle in implementing diphtheria prevention was lack of public awareness of individuals to protect their families through immunizations, even though each health centre has provided adequate vaccines. A doctor at health centre D stated:

"The problem is that the societies did not come to the Health Centre for immunization although they have got counselling. As a result, the immunization was incomplete. Therefore, the problem is lack of public awareness".

Societies in Banda Aceh, as admitted by a doctor at health centre $A$, still refused to administer immunization for their children:

"In terms of education, counselling, we have started it since 2017. Then in 2018, it became a routine program funded by BOK, but it seemed less optimal because of less enthusiasm or responses from the societies. They have been still difficult to understand the importance of immunization and to protect themselves or their families. This is truly very challenging".

One of the factors that have influenced less awareness of the importance of immunization was issues of haram (illegitimate) vaccines and post-immunization incidence (KIPI). A doctor at health centre A believed that the issue of the haram vaccines and a presence of antivaccine groups among societies had significantly influenced the immunization coverage. Some societies did not allow their children to get vaccines because they considered that the vaccines were haram. A doctor at health centre A delivered that:

"One of the obstacles is the existence of antivaccine groups and halal-haram issues in Aceh. Moreover, health centres in Banda Aceh are 
usually located city areas. Consequently, the societies can get information from anywhere. of course, it depends on their education levels; they can receive information from anywhere without filtering beforehand".

Issues about KIPI after DPT immunization also occurred among the societies in Banda Aceh. A main interviewee at health centre B stated that the societies were afraid to get their children immunized because their children would get fever after immunization. A doctor at health centre B explained:

"The problem is, when we usually come to elementary schools to administer immunizations, sometimes without trusted information the parents assume that their children will get fever or suddenly cannot walk after immunizations. Those are what we call as post immunization events; although, in fact it depends on conditions of the children. We have explained those to them".

\section{Identification and management of diphtheria}

In 2017 diphtheria cases were found in all samples of the health centres, but in 2018 only health centre A and B still had diphtheria cases. After a laboratory examination, diphtheria cases at health centre A were identified as suspected diphtheria, while health centre B was identified to have positive diphtheria patients until October 2018.

Health workers in the five samples of health centres had not attempted active identification. Based on information of main interviewees at the five health centres, identification of diphtheria cases was still in a passive way. Diphtheria patients were sometimes diagnosed at other health services, like in a certain private-health service. Diphtheria-suspected patients were coped with referrals to a governmental hospital. Based on reports from the governmental hospital, the Banda Aceh health office contacted the health centres where the patients have had further epidemiological investigations. A doctor at health centre B noted:

"In my experience, during my service at the health centre, we have never had a direct identification of diphtheria cases..."

A doctor at health centre $\mathrm{D}$ also noted: "In 2017, we ever found a patient, but he/ she was not the one who we diagnosed. The patient went to a paediatrician private practice and was referred to a hospital. The hospital reported the case to the health office and then the hospital contacted us. So we didn't meet the patient directly".

There was no coordination between the health centres and other health services in identification and management of the diphtheria. The identification of diphtheria patients in health service units other than the health centres was reported by the health department to the health centres for epidemiological investigations, not for coordination among health service units that might shorten time to take further management.

In an effort to identify the cases quickly, doctors at the health centres had tried to educate public societies about signs, symptoms, and spreads of diphtheria. It was hoped that it could make them check themselves to a health centre if they experienced similar conditions to the diphtheria.

Education about diphtheria in each health centre was held in every month's public health promotion activity, for examples, counselling at schools, activities in posyandu, and on other occasions inviting the public to know more about the diphtheria. This routine education was conducted not only by doctors but also by other health workers by involving young doctors from the Faculty of Medicine, Syiah Kuala University, as part of lecturing activities. The educational activities were by visiting some villages and distributing leaflets or brochures regarding the diphtheria. A doctor at health centre $\mathrm{C}$ told:

"Health promotion combined with educational activity was the activity that we did. It was because at the time diphtheria was booming, so a lot of information was conveyed through leaflets. We also worked with young doctors from Faculty of Medicine, Unsyiah".

Providing education about diphtheria for the public by doctors in the health centres is 
significantly necessary. An interviewee (T2), an expert physician who served in the diphtheria referral hospital stated:

"Education is vital. You must educate people until they know how important it is to prevent the diphtheria, what happened if they were infected and how to identify fast and to get referral fast; therefore, their fatality can be coped with. The frontline is doctors at the health centres".

\section{DISCUSSION}

The numbers of diphtheria immunization coverage in the five health centres had not yet reached national targets, and this condition indicated needs of serious concerns. Based the results of Riset Kesehatan Dasar (Riskesdas) 2018, coverage of completely basic immunization in Indonesia was only $57.9 \%$, whereas in province of Aceh average numbers of completely basic immunization coverage was still below the national average $(20 \%){ }^{10}$

Immunization is classified as a primary prevention against various infectious diseases that are very effective and inexpensive. ${ }^{11}$ Completely basic immunization helps to protect infants from infectious diseases that can be prevented by the immunization (PD3I). Some researchers have proved benefits of the immunization. A research conducted by Hidayati found that toddlers who did not get diphtheria immunization had seven times of greater risks of diphtheria than toddlers who had get diphtheria immunization. DPT vaccine given could help toddlers to form antibodies so that the toddler's body get immunity against the diphtheria. ${ }^{12}$ Other researches also showed that immunization status was very influential for incidences of diphtheria infection. Children who had been immunized with DPT three times, as recommended by WHO, would have active immunity in their bodies. ${ }^{13}$ Similarly, Mardiana stated that completelly basic immunization was a component that greatly influenced risks of diphtheria in East Java in 2016 compared to population density which was equal to 0.33 times. ${ }^{14}$

This study found that doctors in the health centres had tried to increase immunization coverage in their working areas by conducting workshops or educational activities. The educational activities designed in a form of health promotion program (Promkes) were funded by Health Operational Assistance (BOK). There were no problems in term of financing. The funds were sufficient and could be utilized very well in each health centre.

The numbers of immunization coverage in each health centre that had not reach the national target, according to the researchers, were caused by erroneous strategies in terms of education as they had less implications.

There are six principles of family-based treatment. Doctors who work in primary services are expected to be able to apply the principles to improve quality of their primary services. These principles refer to WHO and the world organization of family doctors(WONCA), which include holistic and comprehensive ways, continuity of care, prioritized prevention, coordinated service, patient care in his/her family, and services that consider aspects of environment, occupation, and community around him/her. ${ }^{15,16}$

Doctors at the health centres had tried to implement preventive action by conducting counselling and education about immunization to prevent diphtheria. However, they had not fully implemented the principles of family medicine in a comprehensive manner, as they should understand social and psychological conditions of societies, not just in physical terms. Applying the principles comprehensively will help them to understand main causes of societies to immunize their children. Certainly, the doctors at the health centres should use some approaches for the societies.

The educational activity, the counselling given by the doctors in the health centres in Banda Aceh to increase immunization coverage had not answered issues developing in the societies. They only explained the importance of immunization, without explaining the answers to main problems. The doctors should be able to explain that DPT vaccine is a halal vaccine. The doctor should ensure that methods and components of DPT 
vaccines are halal. The doctors should also invite religious leaders to take part in their educational activities. Acehnese people religiously tend to trust what their religious leaders say, so this way will lead the societies to immunize their children because they will believe that the vaccines are halal. Furthermore, the government also should support in ensuring the societies about the halal issues in the immunization.

Halal or haram issues of the vaccines have also happened at moeslim countries such as Malaysia, Afghanistan, and Pakistan. In Malaysia, its government issued a law that require every parent to vaccinate their children as part of their rights. ${ }^{17}$ In this research, further information is needed on how the government,are involved in efforts to support the immunization program and deal with issues of haram vaccines in Banda Aceh.

This study also found that parents were worried about the post KIPI which would be fatal for the health of the immunized children. The results of this study are in line with a research conducted at one of governmental hospitals in Banda Aceh showing the biggest reason why the parents did not immunize their children was anxieties about effects that will occur after the immunization (KIPI). There were also influences of education of parents, especially mothers, to the completeness of their children immunization. ${ }^{18}$

Another research conducted in district of Bangkalan concluded that a reason why parents did not bring their children to be immunized was they were afraid that their healthy children would get sick after DPT immunization. In addition, some parents who had previously immunized their children for DPT 1 felt that their children would experience KIPI again. ${ }^{19}$

This study also found that levels of education and the levels of accessibility to technology and information affect awareness of societies to immunize their children. Some doctors reported that societies in their working areas began to understand the importance of immunization after Banda Aceh was identified as a diphtheria outbreakarea. Societies who received positive information about the importance of immunization would certainly fortify their children with complete immunization; meanwhile, societies who received negative information about immunization would be difficult to understand the importance of immunization and disallow their children to be immunized. ${ }^{20}$

This study could strengthen a research at health centre of Bendo, in Magetan concluding that parents who had proper education and knowledge about immunization tended to have completely basic immunization for their children compared to parents who had less education and knowledge. ${ }^{21}$

However, according to a research conducted by Septariani et al., levels of education did not affect attitudes of parents, especially mothers in immunizing their children. Based on the study conducted in Sukarapih village, Sukasari subdistrict, it was found that counselling affected mothers' knowledge. Increasing knowledge of the mothers had not affected their attitudes to immunize their children. There was no willingness of the mothers to change their attitudes because they believed what their societies believed, as they still trusted to some respected people. ${ }^{22}$

This study had several limitations. The researchers did not look further into levels of education of the societies in each health centre. Also, they did not observe how roles of the antivaccine groups in spreading their influences to the societies. Therefore, this study could not answer whether there was a relationship between the presence of diphtheria cases and the levels of education.

Diphtheria cases were identified passively in all the samples of the health centres. It was classified as passive identification because it only depended on when people came to get treatments at the health centres. It could be classified as active identification when the doctors or health workers conducted coordinated and continuous activities through good communication with everyone in health centres and with private clinics or other health services other than 
hospitals to identify patients with diphtheria symtomps. ${ }^{23}$

Based on information of main interviewees in all health centres, it was found that diphtheria patients were diagnosed in other health services besides the health centres, like practices of specialists. This study did not conduct further study on the health services where patients were found and how patients were in these health services. It only focused on doctors at the health centres as its main subjects.

To identify diphtheria cases, the health centres had not yet applied the principles of family medicine, especially a principle of coordinated care, so that the identification was still passive. There were no good coordination and communication with colleagues who worked around the health centres, private clinics or other health services in identifying the diphtheria cases.

The passive identification indicated that it needed to improve management of the health centres to prevent spreads of the infectious disease, the diphtheria. The doctors did not implement a principle of continuity of care, that continuously paying attention to either healthy or ill conditions of societies around their working areas. ${ }^{24}$ This could be seen by absence of active efforts of the doctors, such as continuous screening of societies who might have symptoms of diphtheria. They just waited until the societies reported or came for treatments with diphtheria symptoms.

Passive identification was also often found in a spread of other infectious diseases such as tuberculosis. According to a research conducted by Wijayanti, identification of tuberculosis cases required proper management like planning, organizing, actuating, and controlling. Likewise, it was expected to be applicable identifying the diphtheria cases.

This study found that there had been efforts by the doctors at health centres to increase public knowledge about diphtheria. The doctors and other health workers had held routine counselling continuously to explain signs and symptoms of diphtheria and its complications or consequences. It was expected that everyone who had symptoms similar to diphtheria could immediately check himself or herself to the health centres for further diagnosis. A research in Blitar revealed that risk factors for diphtheria, in addition to children under the age of 15 years, also included societies with less knowledge of diphtheria. People who did not understand about dangers of diphtheria would get risks of diphtheria easily because they did not know signs, symptoms and prevention of the diptheria. ${ }^{26}$ This was also supported by Utami who stated that people with lower knowledge of diphtheria, would be get 16.4 times of risks higher than people with knowledge. Therefore, societies needed to increase their knowledge about diphtheria through counselling conducted not only by doctors, but also by all health workers and cadres. ${ }^{27}$

This study did not examine community responses in receiving diphtheria information. Researchers only interviewed doctors at health centres without conducting interviews with societies around the health centres.

\section{CONCLUSION}

The roles of doctors at the health centres in applying principles of family medicine to prevent and control diphtheria in Banda Aceh still faced obstacles because the principles could not be fully implemented in a sustainable and coordinated way. They had tried to apply only one of the principles, especially the preventive principle, but they had not applied the comprehensive principle. With comprehensive knowledge, they would be able to identify characteristics of societies in their working areas; therefore, they can identify main problems that make people reluctant to immunize their children.

They also had not yet applied the principle of continuity of care, caring for the societies not only when they were sick, but also when they were healthy. This could be seen in the absence of active efforts of doctors in terms of identifying diphtheria cases. 


\section{CONFLICT OF INTEREST}

There was no conflict of interest.

\section{ACKNOWLEDGEMENT}

The researchers would like to thank all the interviewees, including the doctors at health centres in Banda Aceh, health office of Banda Aceh, and the doctors at the public hospital Dr. Zainoel Abidin.

\section{REFERENCES}

1. Irawan H. Diphteria:Re-emerging disease dalam current evidences in pediatric emergencies management. Jakarta: Departemen Ilmu Kesehatan Anak FKUI/RSCM. 2014.

2. Sariadji K, Sunarno \& Putranto R. Penerapan diagnostik laboratorium pada kasus tersangka positif difteri pada kejadian luar biasa di kota Pontianak, Kalimantan Barat. Jurnal Biotek Medisiana Indonesia. 2014; 3(1) : 31-5.

3. Afif. Aceh jadi provinsi ketiga di indonesia pengidap difteri terbanyak. 2018. https:// www.merdeka.com/peristiwa/aceh-jadi-provinsi-ketiga-di-indonesia-pengidap-difteri-terbanyak.html.

4. Anggraeni ND, Yosephine $\mathrm{P}$, Natalia U, Mazanova D. Pedoman pencegahan dan pengendalian difteri: Edisi pertama. Jakarta: Kementerian Kesehatan Republik Indonesia. 2017.

5. Mardiana D. Pengaruh imunisasi dan kepadatan penduduk terhadap prevalensi penyakit difteri di Jawa Timur. Jurnal Berkala Epidemiologi. 2018; 6(2) : 123-9.

6. Kurniawan R, Yudianto, Boga H, dan Soenardi TA. Profil kesehatan Indonesia tahun 2016. Jakarta: Kementerian Kesehatan Republik Indonesia. 2017.

7. Wedhani RA. Leadership in doctor-patient relationship: Implementation on patient's case management in primary care. Medical Journal of Indonesia. 2017; 26(2) : 158-66.

8. Sarosa S. Penelitian kualitatif: Dasar-dasar. Jakarta: PT.Indeks. 2012.

9. Sugiyono. Metode penelitian pendekatan kualitatif kuantitatif. Bandung: Alfabeta. 2010 .
10. Badan Penelitian dan Pengembangan Kesehatan. Riset Kesehatan Dasar. Jakarta: Kementerian Kesehatan Republik Indonesia, 2018.

11. Ranuh I. Imunisasi upaya pencegahan primer, dalam: Ranuh I, Suyitno H, Hadinegoro $\mathrm{S}$, Kartasasmita $\mathrm{C}$, Ismoedijanto, Soedjatmiko. Pedoman imunisasi di Indonesia. Edisi ketiga. Jakarta: Satgas Imunisasi-IDAI. 2008.

12. Hidayati, R. Faktor-faktor yang mempengaruhi angka kejadian difteri di kota Padang. UNES Journal of Social and Economics Research (JSER). 2017; 2(2): 180-7.

13. Saifudin N, Wahyuni C, \& Martini S. Faktor risiko kejadian difteri di kabupaten Blitar tahun 2015. Jurnal Wiyata Penelitian Sains dan Kesehatan. 2017; 3(1): 61- 6.

14. Mardiana D. Pengaruh imunisasi dan kepadatan penduduk terhadap prevalensi penyakit difteri di Jawa Timur. Jurnal Berkala Epidemiologi. 2018; 6(2): 123-9.

15. Fujiati I. Dasar-dasar kedokteran keluarga. Medan. Universitas Sumatera Utara. 2005.

16. Anggraini MT, Novitasari A, Setiawan MR. Buku ajar kedokteran keluarga. Semarang: Fakultas Kedokteran Universitas Semarang. 2015.

17. Ali A, Kah SL, Allah B, Yaser MA, Moklesur RS, Long CM, Tahir MK. Outbreak of vaccine-preventable diseases in muslim majority countries. Journal of Infection and Public Health. 2017; 11(6): 153-5.

18. Thaib TM, Darussalam D, Yusuf S, Andid R. Cakupan imunisasi dasar usia 1-5 tahun dan beberapa faktor yang berhubungan di poliklinik anak rumah sakit ibu dan anak (RSIA) Banda Aceh. Sari Pediatri. 2013; 14(5): 283-7.

19. Utama F, Catharina U.W, Martini S. Determinan kejadian difteri klinis pasca sub PIN difteri tahun 2012 di kabupaten Bangkalan. Jurnal Berkala Epidemiologi. 2014; 2(1); 71-82.

20. Triana V. Faktor yang berhubungan dengan pemberian imunisasi dasar lengkap pada bayi tahun 2015. Jurnal Kesehatan Masyarakat Andalas. 2015; 10(2): 123-35.

21. Sari D, Basuki S \& Triastuti N. Hubungan 
pengetahuan ibu dengan imunisasi dasar dengan kelengkapan imunisasi dasar bayi di wilayah kerja puskesmas bendo kabupaten Magetan. Biomedika Jurnal. 2016; 8(2): 6-12.

22. Septariani R, Susanti A \& Nirmala S. Pengaruh penyuluhan mengenai imunisasi terhadap pengetahuan dan sikap ibu di desa sukarapih kecamatan Sukasari. Jurnal Sistem Kesehatan. 2015; 1(2): 48-54.

23. Kementerian Kesehatan Republik Indonesia. Petunjuk teknis pelaksanaan imunisasi dan surveilans dalam rangka penganggulangan kejadian luar biasa (KLB) difteri. Jakarta: Direktorat Jendral Pengendalian Penyakit dan Penyehatan Lingkungan Kementerian Kesehatan Republik Indonesia. 2013.

24. Murtagh J. Paradigms of family medicine: Bridging traditions with new concepts; Meeting the challenge of being the good doctor from 2011. Asia Pacific Family Medicine. 2011; 10(9): 1-4.

25. Wijayanti R. Analisis Faktor Manajemen di Puskesmas dalam meningkatkan case detection rate (CDR) tuberkulosis. Jurnal Kesehatan. 2016; 4(1): 61-69.

26. Alfiansyah G. Penyelidikan epidemiologi kejadian luar biasa difteri di kabupaten Blitar tahun 2015. Preventia. 2017; 2(1).

27. Utami, A. Faktor yang mempengaruhi kejadian penularan difteri di kota Blitar propinsi Jawa Timur (Disertasi). Surabaya: Universitas Airlangga. 2010. 